\title{
Assessment of water quality of Garmat Ali river for irrigation purposes
}

\author{
Dina A.Yaseen, Saad Abu-Alhail*, and Haider A. Khanfar \\ Department of civil Engineering, College of Engineering, University of Basrah, 61004,Basra city, Iraq.
}

\begin{abstract}
This study investigates the suitability of Garmat Ali river (Iraq) for irrigation uses. Two stations were chosen: station $\mathrm{A}$; far from any polluted water discharge point, and station $\mathrm{C}$; near to a very contaminated water discharge point). Water samples were picked up and tested for $\mathrm{pH}$, electrical conductivity, total dissolved solids, sodium, potassium, calcium, magnesium, bicarbonate, sulfate, chlorine, and nitrate. Three samples were collected in January and March 2019 from each site, to reflect the wet season in Iraq. Besides the classification of water quality parameters of Garmat Ali river for watering, other parameters were also calculated, such as sodium adsorption ratio, soluble sodium percentage, exchangeable sodium percentage, magnesium hazard, kelly ratio, permeability index, and potential salinity. According to the Food and Agriculture Organization (FAO) guidelines, the overall results showed that the salinity and chlorine were within the range that causing severe problem to plants. In addition, sodium toxicity and hazard were classified the river water as unsuitable for irrigation. Potential salinity was under the class of unsuitable for irrigation. Bicarbonate hazard was under the category "slight to moderate". However, the remaining parameters were within the accepted range. Most of the contaminants were higher in the polluted station.
\end{abstract}

\section{Introduction}

The main water resources in the world are the rivers, glaciers, ponds, lagoons, rainfall, and ground water. These resources are generally used either for drinking or for many economic fields, such as irrigation, animals' production, manufacturing, fisheries, hydropower production, and other activities [1]. However, it is reported that around seventy percent of the water consumption in the world is for agricultural uses, and the major part of this quantity is utilized for grasses and plants' irrigation. Whereas, the rest is consumed for animals and other farm activities.

Rivers are counted to be the main sources of watering, especially in the tropical areas. This because the rainfall in these regions is not reliable for irrigation purposes as the precipitation is highly irregular and it is only ranged between 100 and $200 \mathrm{~mm}$ annually [2]. But, these sources may comprise noticeable amounts of chemical materials and dissolved salts that could decrease the plant production or adversely affect the soil productivity [3]. [4] mentioned that the irrigation water, may be of bad quality, as it carries the pollutants that are occurred naturally in the rivers environment or generated by humans' (industrial or domestic) activities or both of them. Therefore, studying the quality of irrigation water is necessary for safe usage.

Many studies have been reported to investigate the quality of surface and ground water in Iraq and other countries for irrigation. This evaluation is very important, especially in arid and semi-arid areas that suffer from water scarcity problem, to specify the characteristics of water based on standard limits. [3] found that the restriction degree of using the Al-Kifl river in AlHindiya city (Iraq) for irrigation is low. [4] showed that river Diyala water (Iraq), to some extent, is appropriate for irrigation. The water of the Benin-Owena river basin (Nigeria) has been evaluated as moderately acceptable for irrigation [5]. [6] assessed the physicochemical properties of Shatt Al-Arab river and its branches (Iraq) in 2016. Authors concluded that the river water belongs to medium class, and the branches classification was within the worst case. [7] evaluated the water characteristics of East Hammar marsh in Iraq. The water quality (WQ) of Garmat Ali river has been examined during 2015-2016 based on the temperature, salinity, and $\mathrm{pH}$ [8], and the river water classified as a worse. However, these parameters were not enough for full evaluation. Therefore, the study of irrigation WQ of Garmat Ali river has become essential to show whether the water is appropriate for land watering and safe to plants and soil.

The aim of present research is to evaluate the suitability of Garmat Ali river for irrigation purposes by measuring and analyzing the irrigation WQ parameters of the river. These parameters are included: electrical conductivity (EC), total dissolved solids (TDS), sodium adsorption ratio (SAR), kelly ratio (KR), potential

\footnotetext{
*Corresponding author: saad.arab@uobasrah.edu.iq
} 
salinity (PS), permeability index (PI), exchangeable sodium percentage (ESP), magnesium $(\mathrm{Mg})$ hazard, chloride $(\mathrm{Cl})$ hazard, calcium $(\mathrm{Ca})$, sodium $(\mathrm{Na})$, nitrate $\left(\mathrm{NO}_{3}\right)$, bicarbonate $\left(\mathrm{HCO}_{3}\right)$, sulfate $\left(\mathrm{SO}_{4}\right)$, potassium $(\mathrm{K})$, and $\mathrm{pH}$. Water temperature, turbidity $(\mathrm{Tu})$ and dissolved oxygen (DO) are also assessed.

\section{Material and Methods}

\subsection{Study region}

Garmat Ali river, situated in the north of Basrah city (south of Iraq), is a waterway between the east Hammar marsh and Shatt Al-Arab river (Figure 1). This river is considered as a source of irrigation regarding the arears around this river. Garmat Ali river covers a distance of about $6 \mathrm{~km}$ length and $280 \mathrm{~m}$ width. The mean depth is 9 $\mathrm{m}$. This river was subjected to multiple impacts from hydrological and human activities. After inundation of the southern marshes in 2003, the East Hammar marsh was mainly received the water from Euphrates river and entering Garmat Ali river then Shatt Al-Arab river that finally flows into the Arabian Gulf. Thus, Garmat Ali river influenced by the water from Euphrates river, which changed its flow away from the north East Hammar marsh during the last years. This has led to reduce the water level in the marsh clearly, which causing the water salinity higher than before, and consequently impacted adversely on the quality and quantity of the water of Garmat Ali River [8].

Two stations were selected along the river (Table 1). The first station was far from any polluted water discharge point. The second one was near to a very contaminated point (domestic wastewater). Water samples were collected twice during the wet season in Iraq (once in January and the other in March 2019) from each station in sterilized bottles of 0.5 -liter capacity. They were directly sent by using a cool box to the laboratory of Marine Science Centre to be tested for EC, $\mathrm{Ca}, \mathrm{Mg}, \mathrm{Na}, \mathrm{K}, \mathrm{HCO}_{3}, \mathrm{NO}_{3}$, and $\mathrm{SO}_{4}$. However, the other tests were done in the laboratory of civil engineering department according to the standard methods [9]. Temperature records were conducted in the site $\left(15.2{ }^{\circ} \mathrm{C}\right.$ in January and $21.5^{\circ} \mathrm{C}$ in March) and laboratory $\left(18.5^{\circ} \mathrm{C}\right.$ in January and $26.6^{\circ} \mathrm{C}$ in March).

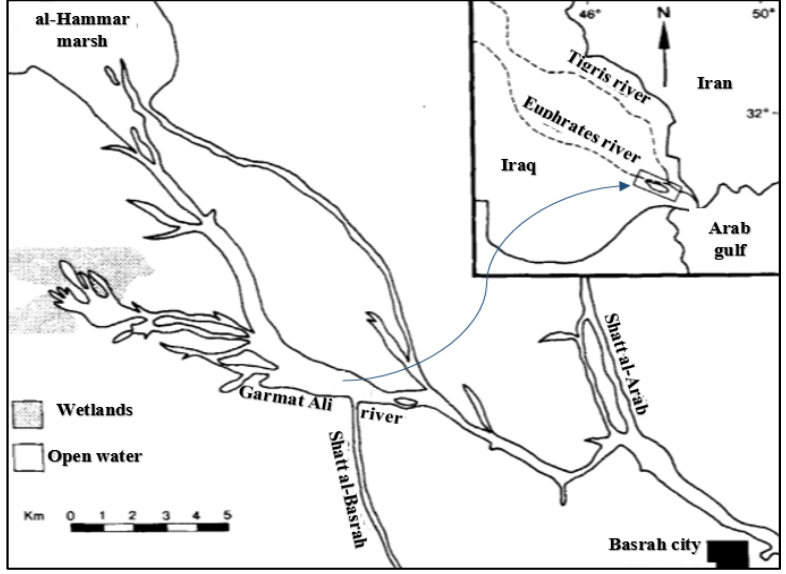

Fig. 1. Map of Garmat Ali River

Table 1. Details of the sampling stations at Garmat Ali river

\begin{tabular}{|c|c|c|c|}
\hline Site number & Description & Latitude & Longitude \\
\hline Station A & Uncontaminated & $30^{\circ} 34^{\prime}$ & $47^{\circ} 45^{\prime}$ \\
& point & $15.26^{\prime \prime} \mathrm{N}$ & $19.24^{\prime \prime} \mathrm{E}$ \\
\hline Station C & Contaminated & $30^{\circ} 34^{\prime}$ & $47^{\circ} 44^{\prime}$ \\
& point & $26.37^{\prime \prime} \mathrm{N}$ & $54.9^{\prime \prime} \mathrm{E}$ \\
\hline
\end{tabular}

\section{Data analysis and calculation}

Irrigation WQ parameters are analyzed using Microsoft Excel 2016. The SAR, SSP, ESP, MH, KR, PS, and PI are calculated according the equations $(1-7)[4,5,10]$. All ions are converted to milliequivalent per liter unit.

$$
\begin{gathered}
\mathrm{SAR}=\mathrm{Na} / \sqrt{ }(0.5(\mathrm{Ca}+\mathrm{Mg})) \\
\mathrm{SSP}=\mathrm{Na} /(\mathrm{Ca}+\mathrm{Mg}+\mathrm{Na}+\mathrm{K}) \times 100 \\
\mathrm{ESP}=(100(-0.0126+0.01475 \times \mathrm{SAR})) / \\
(1+(0.0126+0.01475 \times \mathrm{SAR})) \\
\mathrm{MH}=(\mathrm{Mg}) /(\mathrm{Mg}+\mathrm{Ca}) \times 100 \\
\mathrm{KR}=\mathrm{Na} /(\mathrm{Ca}+\mathrm{Mg}) \\
\mathrm{PS}=\mathrm{Cl} \times 0.5 \times \mathrm{SO} \mathrm{O}_{4} \\
\mathrm{PI}=\left(\mathrm{Na}+\mathrm{HCO}_{3}\right) /(\mathrm{Na}+\mathrm{Ca}+\mathrm{Mg}) \times 100
\end{gathered}
$$

\section{Results and discussion}

\subsection{Collected data}

Table 2 shows the mean, maximum, minimum and standard deviation values of WQ boundaries for irrigation during the study period.

Table 2. Overall physical, chemical, and irrigation index parameters of water samples in study area

\begin{tabular}{|l|c|c|c|c|}
\hline Parameters & Mean & Minimum & Maximum & $\begin{array}{c}\text { Standard } \\
\text { deviation }\end{array}$ \\
\hline PH (-) & 7.1 & 6.9 & 7.6 & 0.3 \\
\hline DO (mg/l) & 6.6 & 5.7 & 7.7 & 0.9 \\
\hline TU (NTU) & 4.3 & 2.9 & 7.2 & 1.7 \\
\hline EC & 4390.0 & 3860.0 & 4600.0 & 307.0 \\
\hline TDS (mg/l) & 2912.8 & 2470.0 & 3136.0 & 269.0 \\
\hline K (meq/l) & 0.8 & 0.4 & 1.2 & 0.3 \\
\hline SO4 & 6.8 & 3.8 & 9.2 & 2.3 \\
\hline
\end{tabular}




\begin{tabular}{|l|c|c|c|c|}
\hline $\mathrm{Ca}(\mathrm{meq} / \mathrm{l})$ & 16.5 & 16.0 & 18.0 & 0.9 \\
\hline $\mathrm{Mg}(\mathrm{meq} / \mathrm{l})$ & 9.1 & 8.0 & 10.0 & 0.7 \\
\hline $\mathrm{HCO} 3$ & 2.7 & 2.0 & 3.2 & 0.5 \\
\hline $\mathrm{Na}(\mathrm{meq} / \mathrm{l})$ & 19.4 & 13.2 & 24.3 & 4.6 \\
\hline $\mathrm{Cl}(\mathrm{meq} / \mathrm{l})$ & 27.9 & 20.1 & 33.1 & 5.5 \\
\hline $\mathrm{NO}_{3}(\mu \mathrm{g} / \mathrm{l})$ & 17.0 & 9.0 & 24.0 & 5.9 \\
\hline $\mathrm{SAR}$ & 5.5 & 3.5 & 6.9 & 1.4 \\
\hline $\mathrm{SSP}(\mathrm{Na} \%)$ & 41.9 & 31.2 & 48.7 & 7.0 \\
\hline $\mathrm{ESP}$ & 6.3 & 3.8 & 8.1 & 1.8 \\
\hline $\mathrm{MH}$ & 35.5 & 33.3 & 37.0 & 1.4 \\
\hline $\mathrm{KR}$ & 0.8 & 0.5 & 1.0 & 0.2 \\
\hline $\mathrm{PS}$ & 101.0 & 38.5 & 152.0 & 49.5 \\
\hline $\mathrm{PI}$ & 47.5 & 37.8 & 54.7 & 6.7 \\
\hline
\end{tabular}

\subsection{Evaluation of water quality values}

\subsubsection{Salinity hazard}

This parameter evaluated according to EC or TDS values, and considered as a main factor that used to check water appropriateness for irrigation. Irrigation water containing very high level of salinity that may concentrated in the root of crops causing yield reduction, as these crops cannot absorb enough water from the salty soil [3]. In this study, the average values of EC and TDS were 4.39 $\mathrm{ds} / \mathrm{cm}$ and $2912.8 \mathrm{mg} / \mathrm{l}$, respectively (Table 2). According to standard limits [4], the restriction on use the water of Garmat Ali river is serve, as EC $>3 \mathrm{ds} / \mathrm{cm}$ and TDS $>2000 \mathrm{mg} / \mathrm{l}$. The values of EC and TDS were higher in station $\mathrm{C}$ during the study period, due to the impact of pollutants in this station. In addition, the mean values in March were higher than those in January indicating that the level of dissolved salts in water has increased. This is interpreted by the higher evaporation levels, due to the higher temperature records in March, which led to increase the ions movement speed and consequently increases the EC. All TDS values during the study period showed the same trend of EC values.

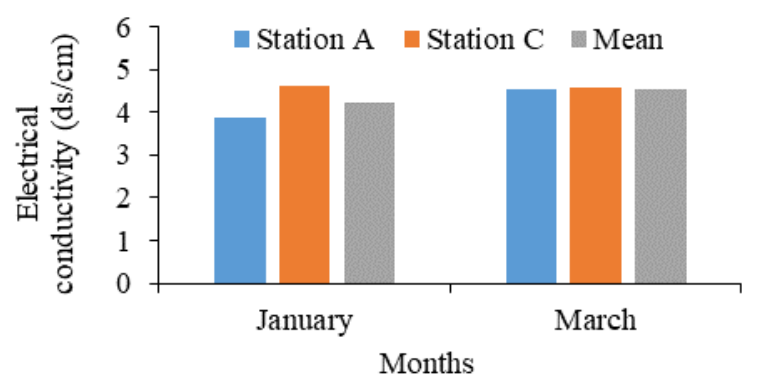

Fig. 2. Variation of EC and TDS values in each station.

\subsubsection{Infiltration hazard}

The SAR is used as an expression for the soil infiltration rate to evaluate water appropriateness for irrigation. SAR at high level shows a noticeable drop in the infiltration rate, which means very limited amount of water is available to plant $[3,4]$. In this study, SAR values varied between 3.53 and 6.85 , the mean was 5.46 (Table 2). Maximum value was in station $\mathrm{C}$ for both months, due to the impact of household discharges near to station $\mathrm{C}$ (Figure 3). According to Food and Agricultural Organization (FAO) limits [10], SAR problem is low in the study area during the wet season, as all values were less than 10 . Based on the US salinity diagram that is used to evaluate the rate of infiltration according to SAR and EC values [4, 5], all samples in this work were within the class C4-S2, which indicated that the water of Garmat Ali river is characterized by high salinity and low sodium. Therefore, its acceptable for watering any type of soil, and only the plants that adapted with high levels of salinity.

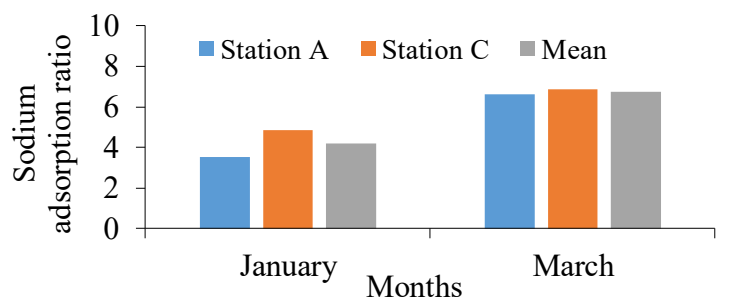

Fig. 3. Variation of SAR parameter in each station.

\subsubsection{Sodium toxicity}

Sodium is the main toxic ion that could cause damage to plants at high concentrations. $\mathrm{Na}$ concentrations are varied between 304 and $558 \mathrm{mg} / \mathrm{l}$ (mean $574.5 \mathrm{mg} / \mathrm{l}$ ) (Table 2). The restriction degree on use the water of Garmat Ali river for irrigation is severe, as all values were higher than $100 \mathrm{mg} / \mathrm{l}$ [4]. Maximum values were at station $\mathrm{C}$ for both months, and all values were higher in March (Figure 4a).

The mean values of SSP, reflecting the percent of soluble sodium in water, is $<60 \%$ (Table 2 ). Water containing high SSP, more than sixty percent, leading to accumulate sodium ions in the soil and consequently reduces the permeability and aeration, and fracture the soil structure $[5,10]$. According to FAO guideline [4], the toxicity of SSP was classified as medium in January and high in March (Figure 4b).

The ESP parameter specified the physical characteristics of the irrigated soil due to the impact of $\mathrm{Na}$ ions in the water. In this study, the mean values were higher in March than those in January, and station C showed higher values than station A, for both months. Also, the calculated values during January were within the acceptable limits [4] of equal to five or lower. However, the values during March were within the ranged that may cause permeability and infiltration problems (Figure 4c). Overall, the river water was unsuitable. 

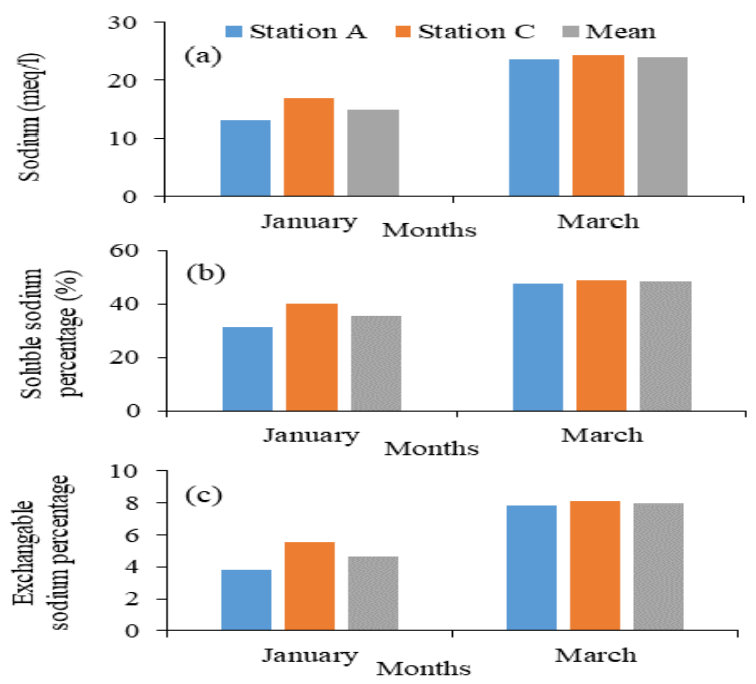

Fig. 4. Variation of Na, SSP, and ESP values in each station.

\subsubsection{Chloride hazard}

The presence of small concentrations of $\mathrm{Cl}$ in the irrigation water is very important to crops. However, $\mathrm{Cl}$ at high levels affect the plant survival [4]. The accumulation of $\mathrm{Cl}$ at concentration of more than 140 $\mathrm{mg} / \mathrm{l}$ (4 meql) negatively affect the plant leaves [11]. In this research, $\mathrm{Cl}$ values in all stations ranged from 712 to $1171 \mathrm{mg} / \mathrm{l}$ (Table 2), indicating severe problem on using the river water, as all the values were more than the standard limit of $300 \mathrm{mg} / 1$ (10 meq/l) [4, 11]. Lower values were in January (Figure 5)

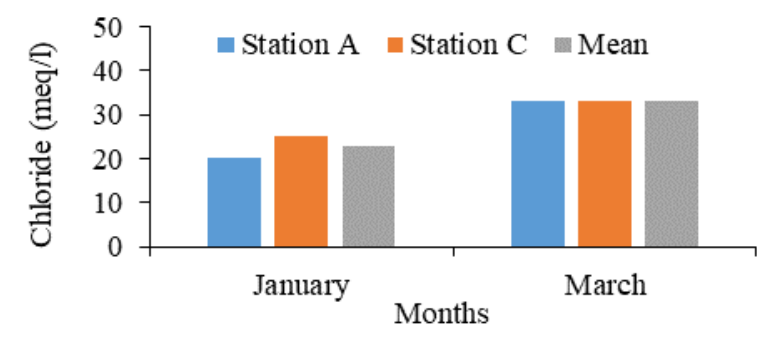

Fig. 5. Variation of $\mathrm{Cl}$ values in each station.

\subsubsection{Magnesium hazards $(\mathrm{MH})$}

The concentrations of $\mathrm{Mg}$ were less than $200 \mathrm{mg} / \mathrm{l}$ (Table 2, Figure 6a), indicating that the river water is safe for irrigation [11]. The calculated data regarding $\mathrm{MH}$ showed that water is suitable for irrigation, as all values were less than 50 [4] (Table 2 and Figure 6b).
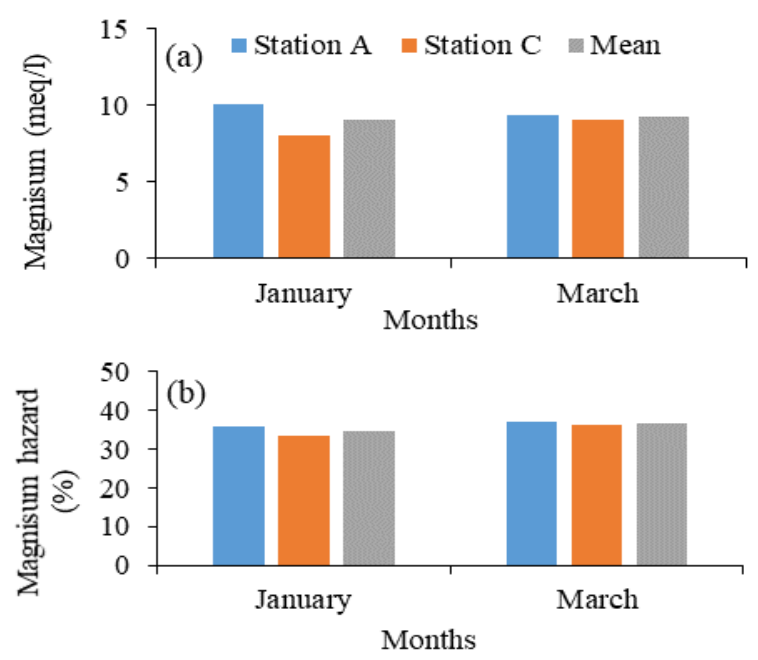

Fig. 6. Variation of $\mathrm{Mg}$ and $\mathrm{MH}$ values in each station.

\subsubsection{Other parameters}

In addition to the above parameters, the following criteria must be taken in account when assessing the WQ for irrigation. The mean concentration of $\mathrm{Ca}$ was 16.5 meq/l (Table 2). All values were within the normal limits for irrigation [4] (Figure 7). The values for both stations were higher in January than those in March. Potassium and sulfate mean concentrations were 0.804 , and 6.8 meq/l, respectively (Table 2). All values of $\mathrm{K}$ and $\mathrm{SO}_{4}$ were within the normal limits for irrigation of $(0-2 \mathrm{mg} / \mathrm{l})$ [4] and (0-20 meq/l) [3], respectively (Figures 8 and 9). Regarding $\mathrm{NO}_{3}$, plants irrigated by water containing extreme amounts of nitrogen grow with many problems related their quality. In this study, $\mathrm{NO}_{3}$ data were within the recommended range $(<45 \mathrm{mg} / \mathrm{l})$ [4] (Figure 10). The average values of bicarbonate were $2.7 \mathrm{meq} / \mathrm{l}$ (Table 2 ). All values were within the normal range for irrigation (0$10 \mathrm{meq} / \mathrm{l})$. Also, the degree of restriction on water use is slight to moderate [4]. All values were higher in March (Figure 11). Potential of hydrogen $(\mathrm{pH})$ values, which characterized the water as acidic or alkaline, affects the growth of plants at extreme levels. All values were within the normal range for watering (Figure 12) between 6.5 and $8.4[3,11]$. In terms of KR, all values were lower than 1 , indicating that the water is suitable for irrigation as mentioned by [10] (Figure 13). PS values, which influenced by $\mathrm{Cl}$ and $\mathrm{SO}_{4}$, were higher than 3 (Figure 14), indicating that the water is not suitable for irrigation [5]. However, PI as indicator of soil permeability which affected by the watering for long durations and the concentration of $\mathrm{Na}, \mathrm{Ca}, \mathrm{HCO}_{3}$ and $\mathrm{Mg}$ in the soil. All values were higher than $25 \%$ and lower than 75\%, (Figure 15) Which means that the water is good for irrigation [5, 10]. Turbidity and dissolved oxygen, which are not used to evaluate the water for irrigation, are recorded and presented in Table 2. No irrigation limits for $\mathrm{Tu}$, but the value of $3.15 \mathrm{NTU}$ indicating to the clarity of water [11]. Higher values were at the polluted station, $\mathrm{C}$, for both months. 


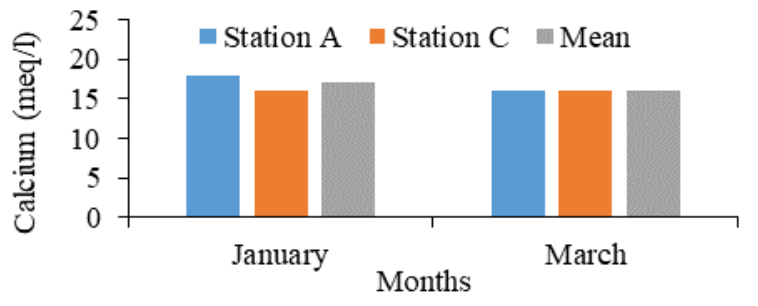

Fig. 7. Variation of Ca parameter in each station

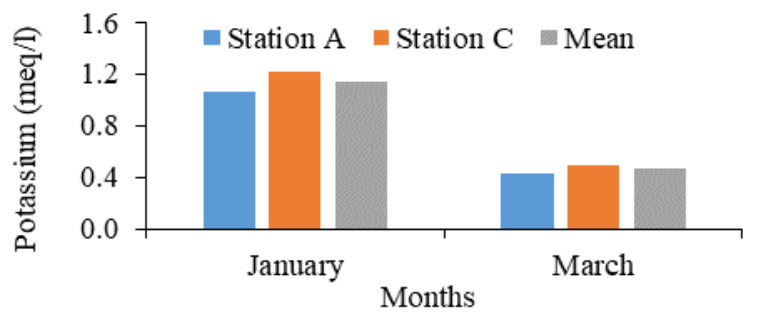

Fig. 8. Variation of K parameter in each station

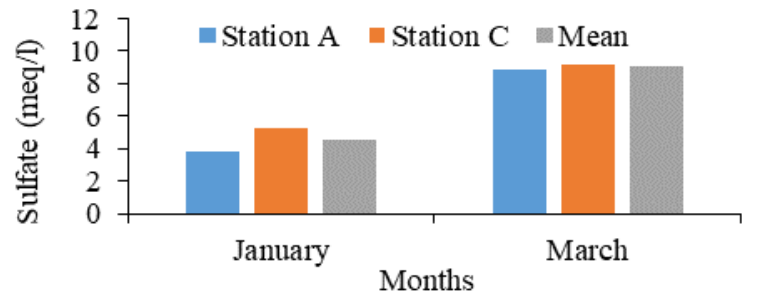

Fig. 9. Variation of $\mathrm{SO}_{4}$ parameter in each station

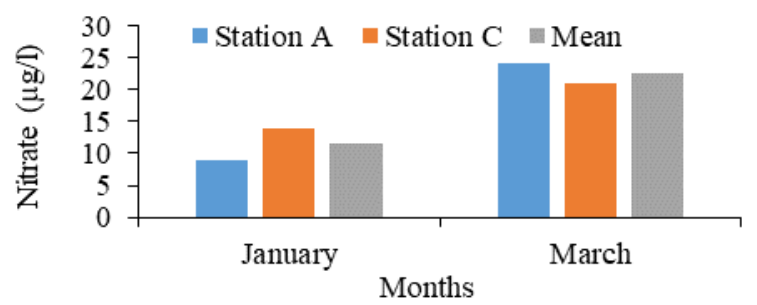

Fig. 10. Variation of $\mathrm{NO}_{3}$ parameter in each station

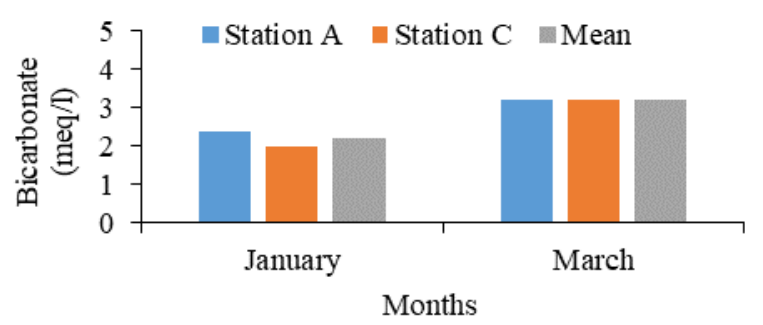

Fig. 11. Variation of $\mathrm{HCO}_{3}$ parameter in each station

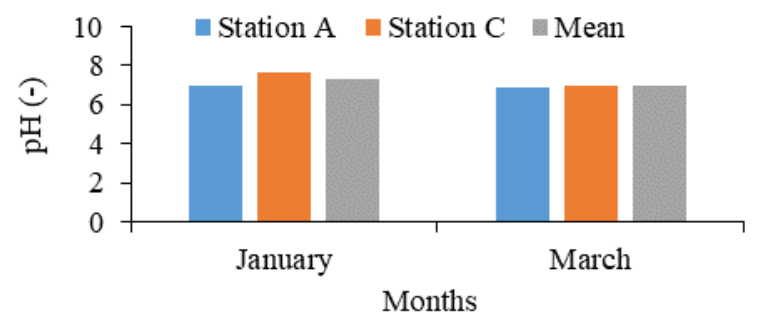

Fig. 12. Variation of $\mathrm{pH}$ parameter in each station

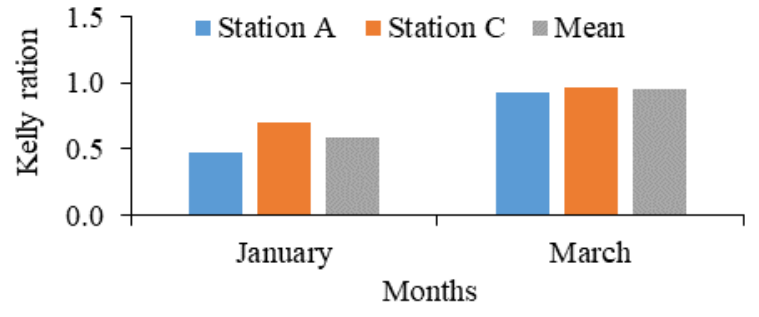

Fig. 13. Variation of Kelly ratio in each station

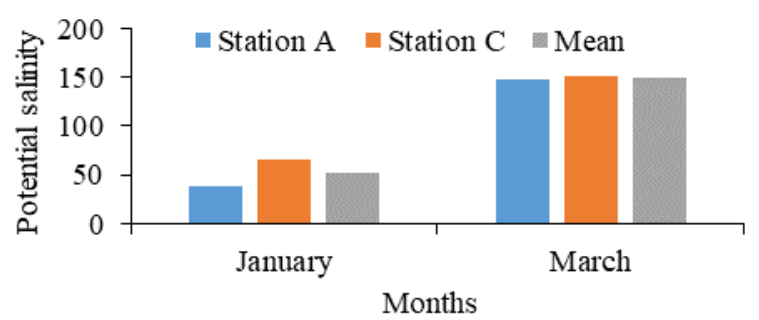

Fig. 14. Variation of PS parameter in each station

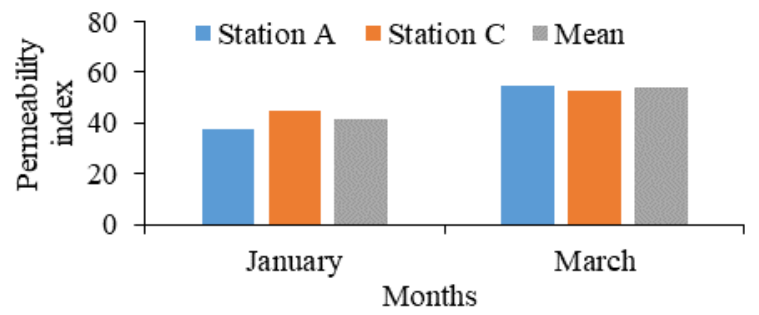

Fig. 15. Variation of PI parameter in each station

\section{Conclusion and recommendations}

This study concluded that the irrigation assessment employing $\mathrm{MH}, \mathrm{KR}, \mathrm{PI}, \mathrm{pH}, \mathrm{Mg}, \mathrm{Ca}, \mathrm{SO}_{4}, \mathrm{~K}, \mathrm{SAR}$ and $\mathrm{NO}_{3}$ showed that the water of Garmat Ali river is suitable for irrigation. Regarding $\mathrm{HCO}_{3}$, the restriction on use the water for irrigation is slight to moderate. However, EC, TDS, Na, SSP, ESP, Cl, and PS values indicated that the river water is unsuitable for irrigation as can cause many problems to soil and plants. According to EC and SAR integration, samples classified to class $\mathrm{C} 4-\mathrm{S} 2$, indicating high salinity with low sodium water. In summary, water of Garmat Ali river is not safe for plant, as high salinity can cause slow growth and leaf burns, as the plants are unable to absorb sufficient quantities of water from salty soil solution. These results were during the main months within the wat season in Iraq, and therefore, it's expected that the water of Garmat Ali will be unsuitable for irrigation during the dry season as well. For further research, its recommended to assess the water quality of Garmat Ali river during all year seasons. In addition to study water quality in terms of heavy metals that affect the plant yield, such as zinc, iron, cadmium, etc. 


\section{References}

1. H. Effendi, River water quality preliminary rapid assessment using pollution index. Procedia Environmental Sciences 33, 562 - 567(2016)

2. J. Al-Khalidi, M. Dima, P. Vaideanu, S. Stefan, North Atlantic and Indian Ocean links with Iraq Climate, Atmosphere 8, 235 (2017)

3. L. A. M. Saleh, Assessment of the Irrigation Water Quality for AlKifl River in Al-Hindya City, Journal of Babylon University 24, 266 (2016)

4. N. H. Hamza, Evaluation of water quality of diyala river for irrigation purposes, Diyala Journal of Engineering Sciences 2, 82-98 (2012)

5. A.O. Talabi, L. O. Afolagboye, A. O. Aturamu, S. W. Olofinlade, Suitability Evaluation of River Owan Water for Irrigation. IOSR Journal of Environmental Science, Toxicology and Food Technology 4, 74-80 (2017)

6. A. Hamdan, A. Dawood, D. Naeem, Assessment study of water quality index (WQI) for Shatt Al-arab River and its branches, Iraq. MATEC Web of Conferences 162, (2018)

7. A. A. Al-Saboonchi, A. R. M. Mohamed and F. K. Raadi, F.K. Assessing the Quality of East Hammar Marsh Water using WQI, Basra, Iraq. Journal of Thi-Qar Science. 5, 24-31. (2014)

8. A. M. Mohamed, K. H. Younis, E. K. Hameed, The ecological condition of the Garmat Ali river, Iraq G.J.B.A.H.S..6, 13-21(2017)

9. APHA, American Water Works Association/ Water Environment Federation, Standard Methods for the Examination of Water and Wastewater, 21st ed, American Public Health Association, Washington, DC, USA, (2005)

10. M.H. Rahimi1, N. Kalantari, M. Sharifidoost, M. Kazemi, Quality assessment of treated wastewater to be reused in agriculture, Global J. Environ. Sci. Manage 4, 217-230 (2018)

11. M. Al-Shammiri, A. Al-Saffar, S. Bohamad, M. Ahmed, Waste water quality and reuse in irrigation in Kuwait using microfiltration technology in treatment, Desalination 185, 213-225 (2005) 